\title{
Sperimentazioni per visualizzare i dati della città
}

\author{
Emanuela Chiavoni \\ Alekos Diacodimitri \\ Federico Rebecchini
}

Abstract

Ogni giorno entriamo in possesso di una grandissima quantità di dati grezzi e non elaborati. Sono informazioni, percezioni spesso intuitive, meraviglie, sensazioni che possiamo decidere di registrare attraverso un ricordo, un appunto mentale o un appunto scritto-grafico.

Possono essere dati soggettivi o emozioni personali, ma anche dati più oggettivi come l'effettiva funzionalità di uno spazio urbano.

Tutto ciò che coinvolge il riconoscimento intellettivo ci può aiutare a capire meglio la città e il nostro rapporto con essa e soprattutto ci può maggiormente orientare per la sua valorizzazione.

Attraverso delle sperimentazioni grafiche (mappe emozionali) all'interno della Data Visualization, si è cercato di visualizzare informazioni che normalmente non vengono associate a scale di valori.

Parole chiave

rappresentazione, visualizzazione, sperimentazione grafica.

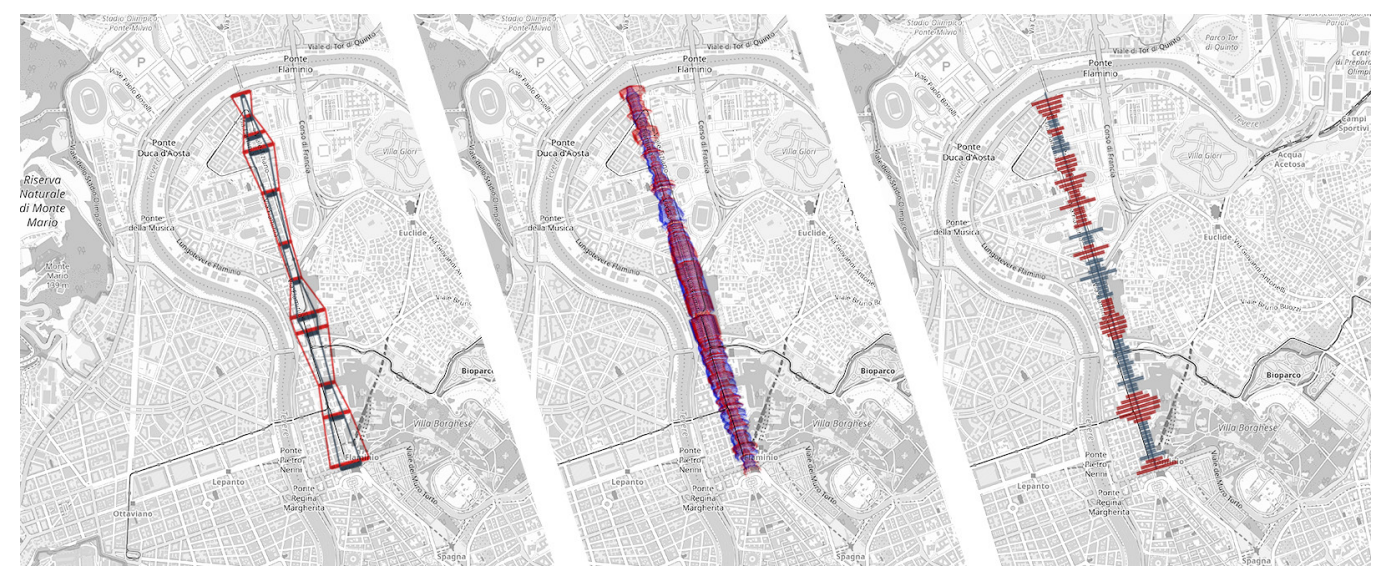




\section{Introduzione}

Questa ricerca parte da un progetto chiamato Atlante delle Emozioni della Città. Una iniziativa che è stata portata avanti nella Capitale Europea della Cultura 2019, cioè Matera. L'Atlante è stato uno dei tanti progetti nati nell'ambito dell'elezione della città della Basilicata a centro culturale italiano. La collaborazione tra il disegnatore Stefano Faravelli e lo scrittore Alessandro Baricco (con gli studenti della sua Scuola Holden) ha dato luogo ad una mappa dai seguenti intenti: "[il progetto] si propone di realizzare una modalità inedita di visita delle città, attraverso l'utilizzo di una Mappa Emozionale creata raccogliendo le memorie e i racconti degli abitanti e, via via, degli stessi visitatori" (fig. I). L'obiettivo è stato quello di sistematizzare, con scopi artistici e divulgativi, ricordi ed emozioni legati al territorio. II risultato è stato una serie di eventi, performance di danza, costruzione di marchingegni, disegni, illustrazioni, numerosi testi, presentati all'interno di un grande spazio espositivo. Per 'Mappa' si intende una mole di oggetti e di testimonianze che possano guidare nella comprensione di uno spazio urbano e di chi lo popola. L'operazione di Faravelli e Baricco è stata l'occasione per rendere fisico e tangibile (o almeno grafico) un corpus di informazioni ed emozioni legate al territorio; un lavoro sensibile, artistico che dà importanza ai dati emozionali non numerabili.

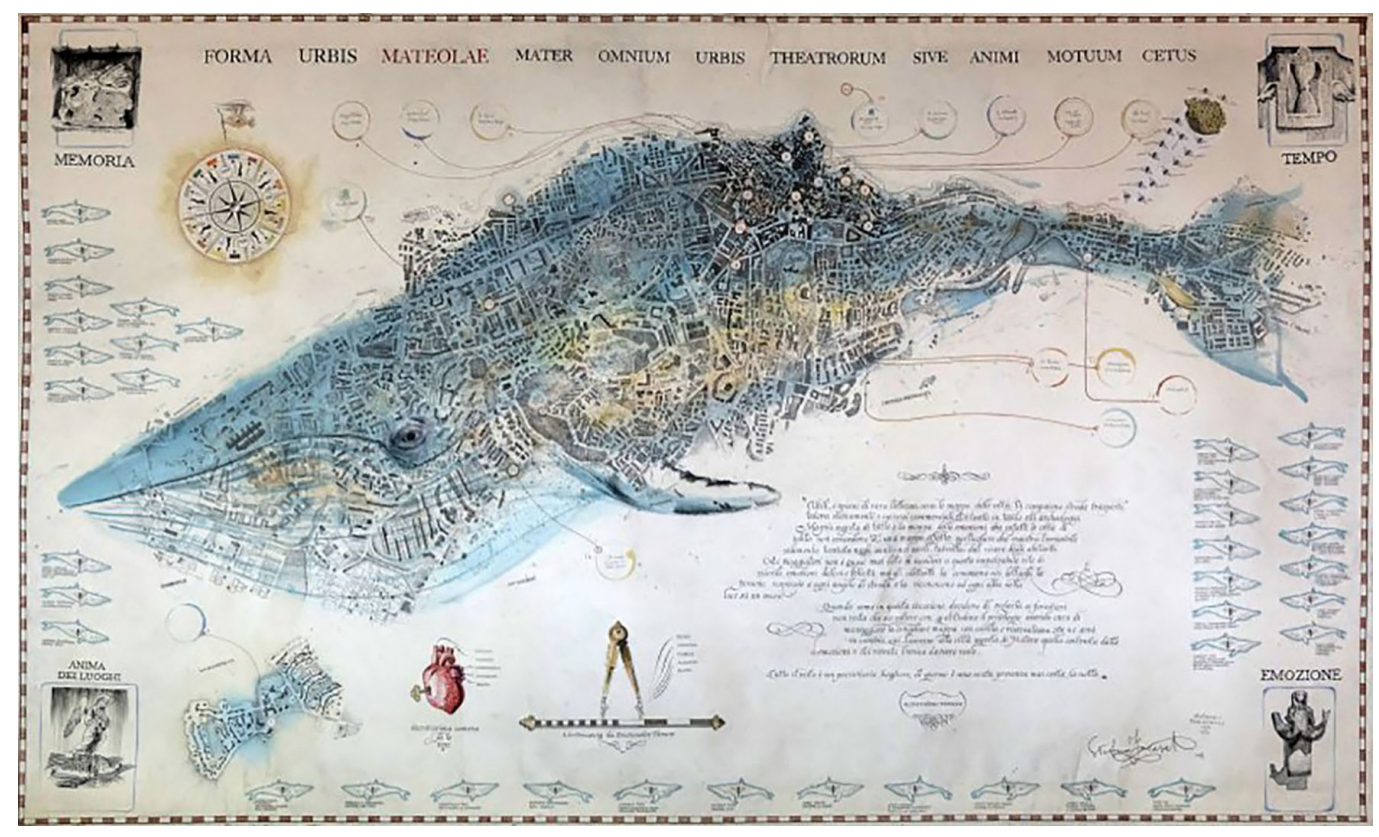

\section{Excursus storico}

L'Atlante delle Emozioni della Città non è un caso unico; la volontà di sistematizzare e di rendere grafici dati che si sono affastellati nel corso del tempo con diverse dimensioni di significato è sempre stato un obiettivo di studiosi e ricercatori. Le infografiche, sempre più presenti su periodici e quotidiani, cercano infatti di aiutarci a comprendere in modo più intuitivo e 'grafico' informazioni altrimenti altamente noiose e di difficile comprensione. Questa volontà di visualizzare dati in modo sistematico comincia agli inizi del I 800 con William Playfair (Diagrammi a torta e istogrammi) e si evolve decenni dopo con l'apporto di Charles Minard e la sua famosa mappa della spedizione russa di Napoleone del I8I2, dove egli analizzava in un singolo elaborato quantità, movimenti e temperature dell'esercito francese. In una singola immagine venivano raffigurate con scientifica cura un grandissimo numero di informazioni. Era una rappresentazione lungimirante e tutt'oggi moderna visiva- 
mente (fig. 2). Da Minard ai giorni nostri si sono fatti grandi passi avanti e oggi possiamo definire la volontà di visualizzare una vera e propria scienza che ha preso il nome di Data Visualization. Si tratta di una scienza liquida, tangente al mondo del design e, ultimamente, anche a quello dell'arte.

La disciplina del Data Visualization sembra rinnovarsi costantemente, grazie agli strumenti che cambiano e all'incredibile mole di dati grezzi di cui veniamo in possesso. Dati grezzi che nella maggior parte dei casi vengono raccolti da grandi aziende e conservati in server, informazioni, di ogni tipo in attesa di elaborazione o a fini commerciali.

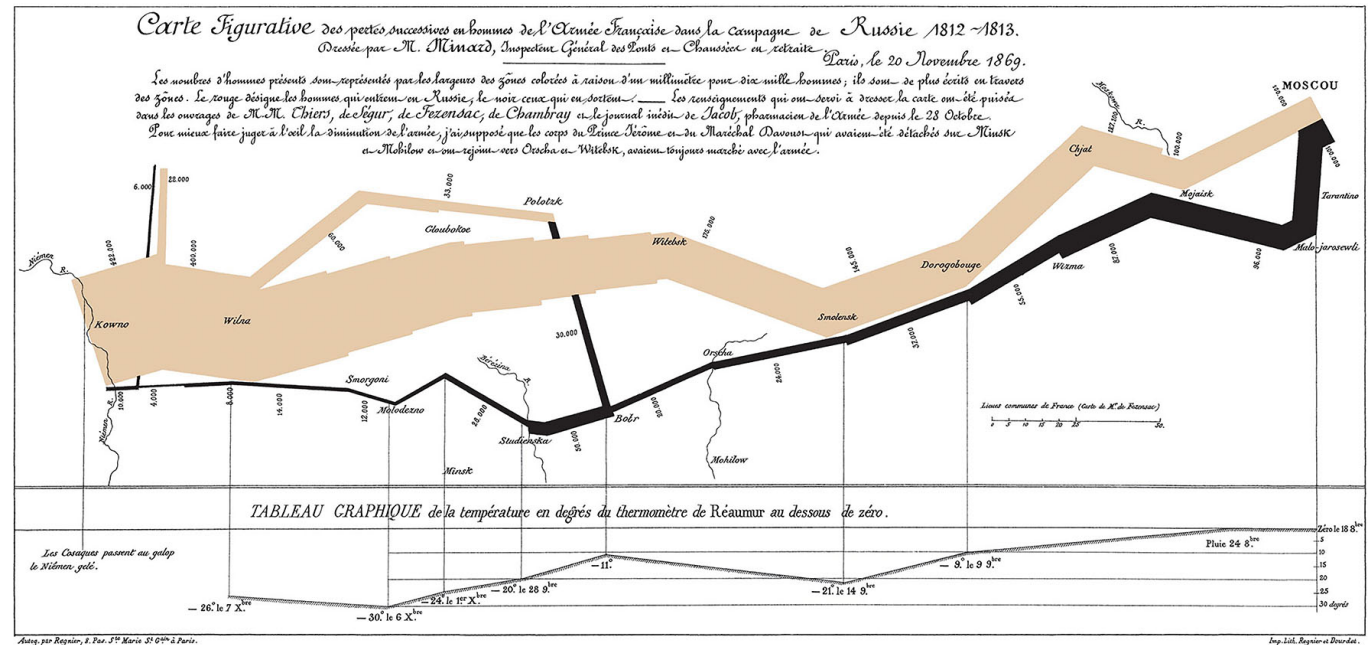

Un personaggio rilevante di questa disciplina è Giorgia Lupi, un'italiana a New York che ha fatto della visualizzazione di dati il suo obiettivo di ricerca; si definisce Information Designer perché propone una forma grafica ad informazioni diverse. È significativo il libro Dear Data, una corrispondenza di cartoline tra Lupi e Stefanie Posavec (information designer); su ogni cartolina che si inviavano le due designer disegnavano a mano grafici di ogni tipo relativi ad informazioni complesse o poco significative. Questo esercizio/gioco ha portato ad una
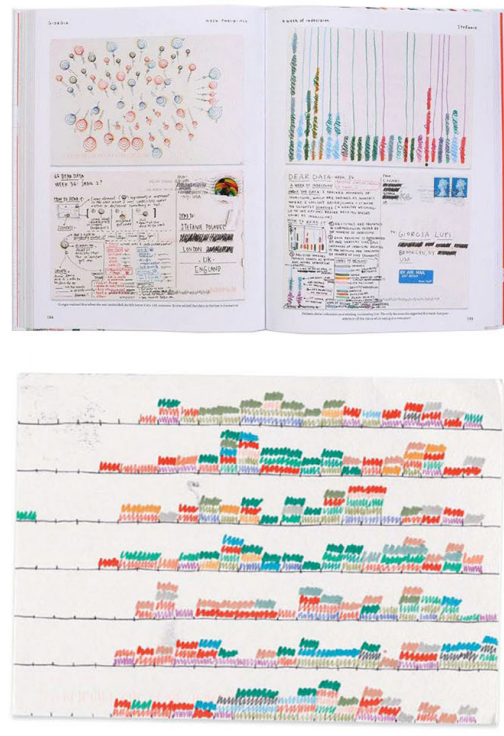

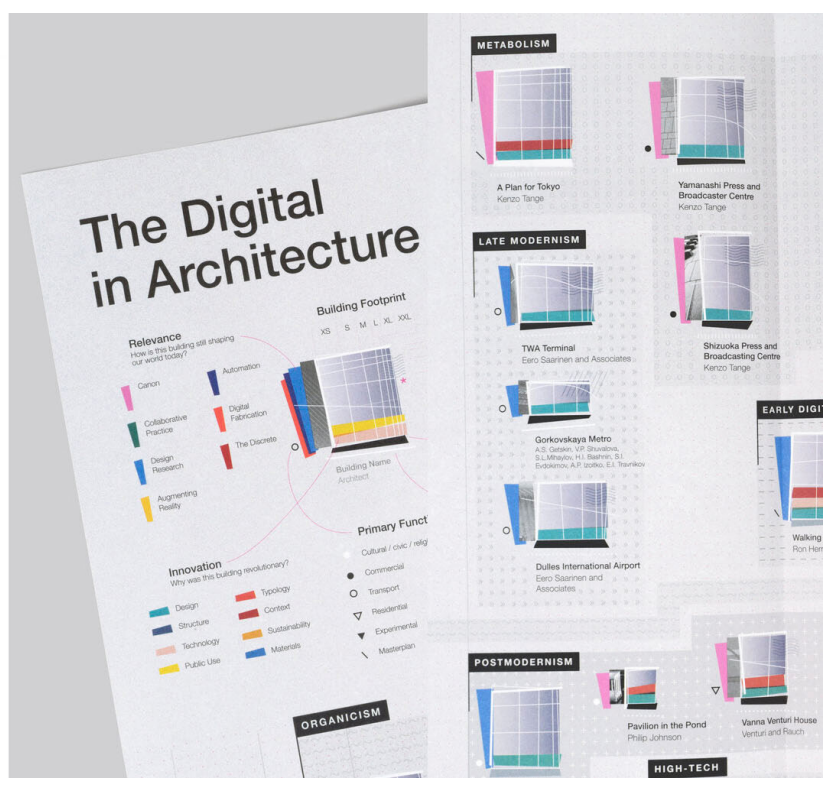

Fig. 3. Dear Data [Lupi, Posavec 2016]; Giorgia Lupi + Space 10, The 2019. 
corrispondenza ricca di spunti per rendere la visualizzazione di dati sempre più completa e stimolante. II lavoro di Giorgia Lupi in ogni progetto si spinge sempre oltre; da gigantesche installazioni (The Room of Change per la Triennale di Milano) fino alla collaborazione con Spacel0 per il progetto The Digital in Architecture dove le caratteristiche di determinate correnti architettoniche formavano elementi atti a creare tante piccole architetture di dati (fig. 3).

Quest'ultimo progetto ha un illustre discendente; nell'anno 2000 l'architetto e teorico Charles Jencks pubblica su Architectural Review un'immagine all'interno di un articolo chiamato The Century is Over, Evolutionary Tree of Twentieth-Century Architecture. Si tratta di un'immagine totale che racchiude al suo interno le varie correnti architettoniche del secolo appena finito. Jencks, autore di numerosi libri e paladino del Post-Modern vuole fare un punto sull'architettura del ventesimo secolo e decide di optare per un albero evolutivo sotto forma di mappa. Una mappa fluida, come lo sono le correnti, e dove i movimenti e i diversi architetti si toccano, si allargano e restringono fino a sparire. L'asse $X$ è quello temporale, l'asse $Y$ invece rappresenta l'approccio di ogni movimento all'architettura. II risultato è una mappa coerente, non oggettiva ovviamente, ma che restituisce sinteticamente un secolo di architettura (fig. 4).

Fig. 4. Charles Jencks, Evolutionary Tree of Twentieth-Century Architecture, 2000.

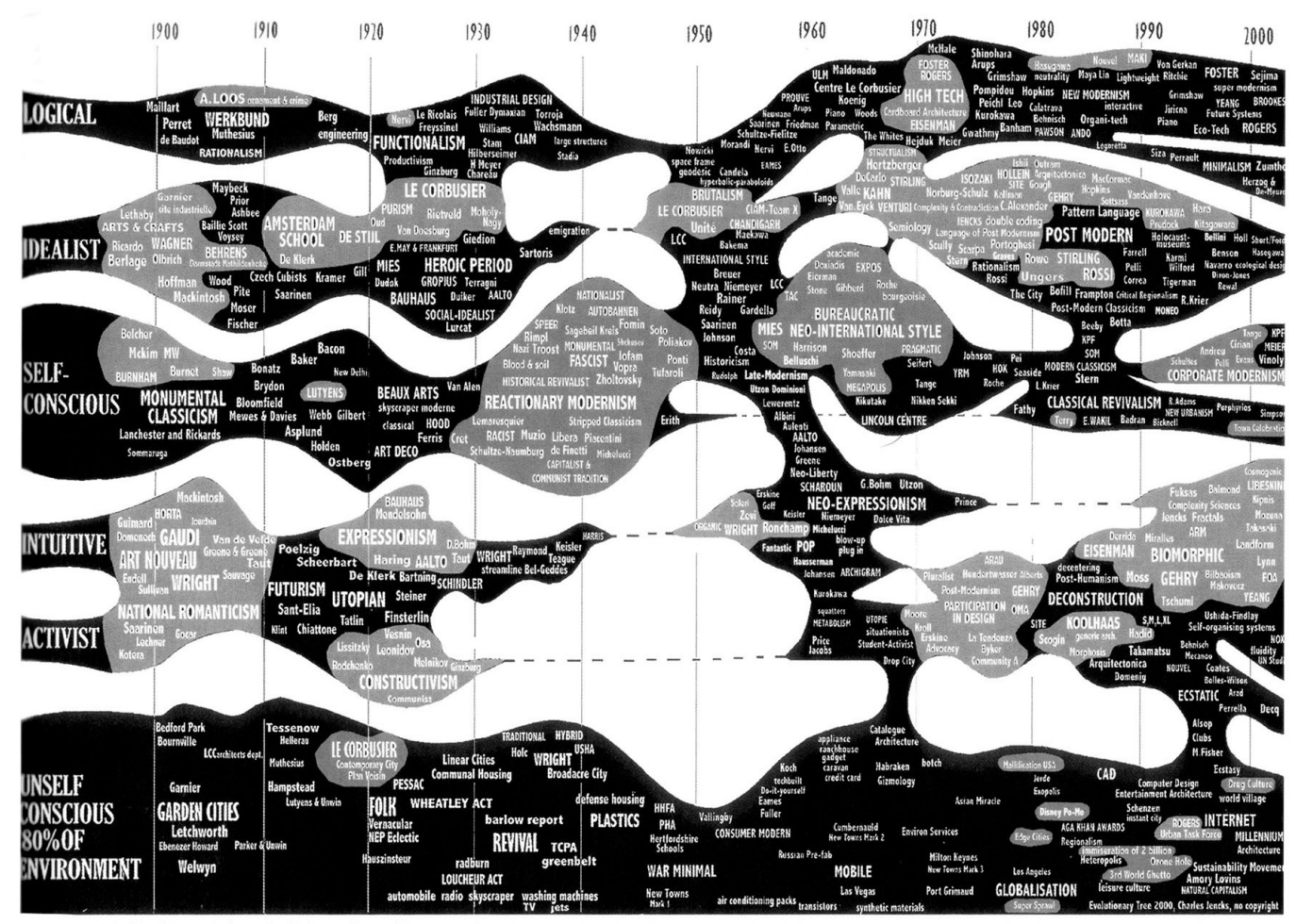

Se in Jencks troviamo chiarezza d'intenti, non si può dire altrimenti di una mappa che tenta di visualizzare la rivoluzione digitale; l'analisi di Baricco nel suo libro The Game ci fa percorrere le trasformazioni che le nuove tecnologie hanno portato al nostro modo di vivere e di pensare. Ogni capitolo delinea parte di una Mappa Mundi che serve ad orientarsi all'interno di questo viaggio; immagina alcune piccole isole, ognuna è un passo significativo della rivoluzione in corso e poi i singoli avvenimenti, come la nascita di Facebook, sono, invece, delle montagne. Si segue un flusso, un fiume, che trascina da una rivoluzione all'altra, sempre in movimento. II concetto è molto interessante anche se le mappe non aggiungono nulla alla narrazione, sono cioè delle immagini fini a se stesse, senza correlazione con i contenuti 
che esprimono se non i nomi delle aziende posti sopra. La mappa completa ci permette di vedere il viaggio compiuto, ma non di visualizzare informazioni fondamentali come date, personaggi rilevanti e ideologia, visibili invece nella mappa di Jencks. Probabilmente per orientarsi in territori inesplorati può essere utile anche qualcosa di simile (fig. 5).

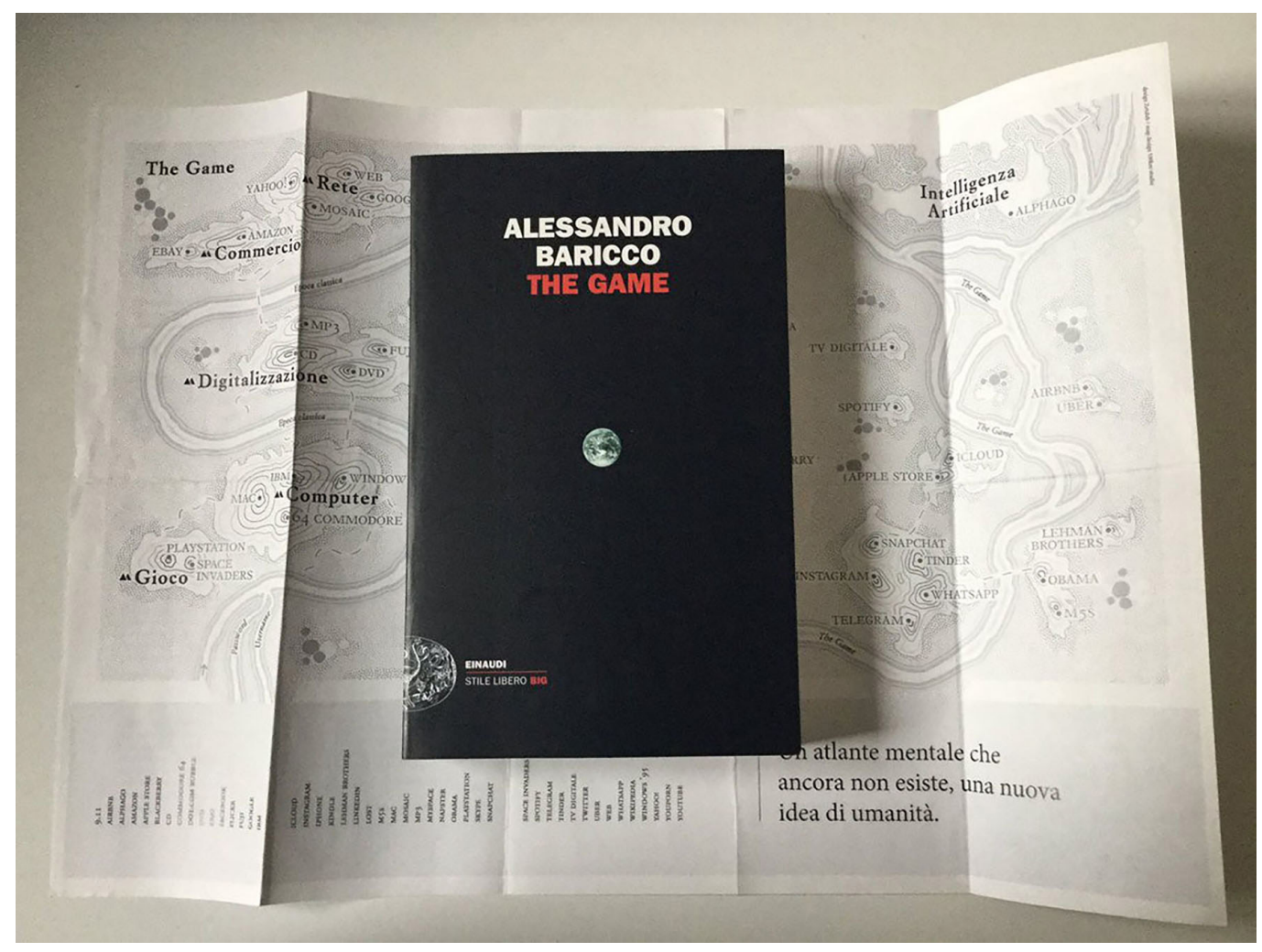

\section{Orientamento, sensazioni, atmosfere}

Quando entriamo nel campo delle emozioni e in quello dei ricordi, la situazione si fa più complicata; rappresentare elementi così effimeri, non numerabili e di difficile descrizione è un'impresa particolarmente difficile.

Nella maggior parte dei casi è obbligatorio affidarsi ad un'astrazione di tali emozioni in forma puramente soggettiva. Ognuno le incanala verso un medium in modo personalissimo ed è quindi difficile effettuare una sovrapposizione dei risultati.

Un esempio di come dati così aleatori possono essere rappresentati è quello Remì, il topo protagonista del film Pixar Ratatouille. Remì fonde nella sua testa sapori ed emozioni e genera un susseguirsi di forme che si attorcigliano e, a volte, esplodono (fig. 6). Vengono visualizzati dati intangibili differenziati con colori e figure sempre nuove, legate da parametri personali del gusto. Se nel film Pixar l'intento è di aggiungere qualcosa ad una narrazione per immagini, il discorso è diverso per l'artista libanese Stephanie Saadè, che nell'anno 20 I 5 realizza un'opera chiamata A Map of Good Memories. Prendendo una mappa del Libano ha tracciato le traiettorie dei suoi viaggi intrapresi per andare ad incontrare persone a lei care o per visitare luoghi particolari. Tutte le traiettorie combinate hanno dato forma ad un groviglio all'interno di una forma chiusa e proprio quest'ultima, completamente campita in oro, diventa un territorio sentimentale, un ritratto geografico dell'artista, disegnato sul pavimento. La Saadè riesce a rendere grafiche e non dispersive una moltitudine di informazioni molto personali (fig. 7). 
Fig. 6. Remì e i sapori, Ratatouille, Pixar 2007
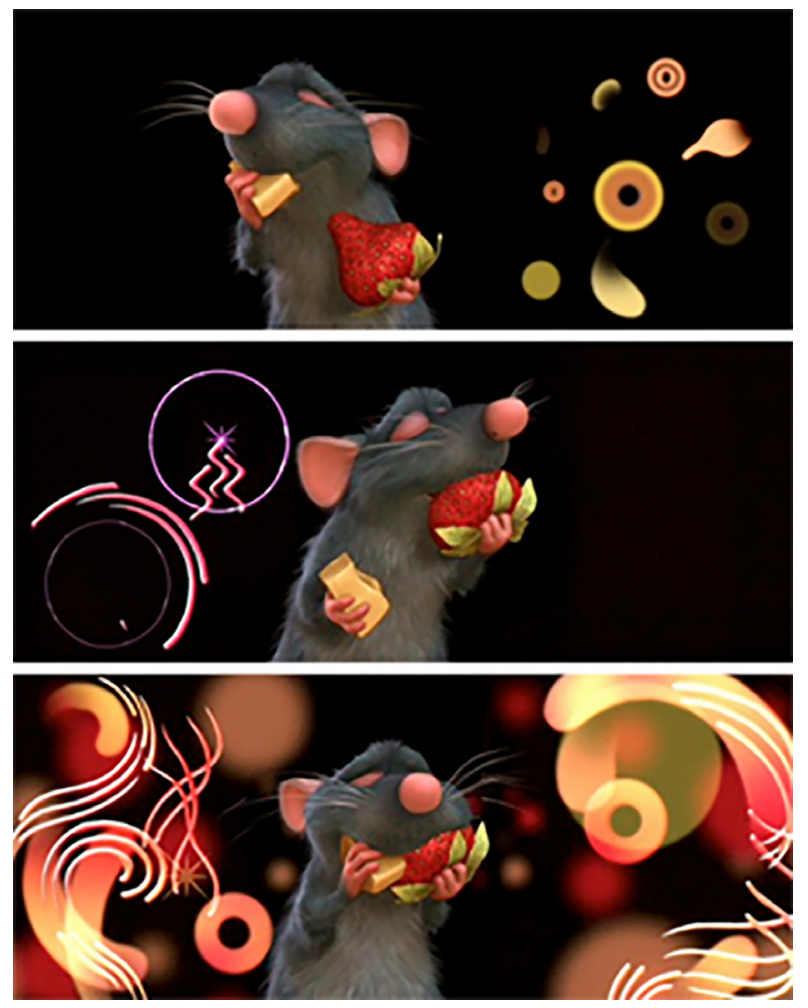

\section{Sperimentazioni}

La prima ipotesi di ricerca è stata quella di lavorare su una personale mappa emozionale della città, delimitando il raggio di azione e di analisi ad un'area romana. Un lavoro necessariamente ispirato al lavoro della Saadè, un lavoro con l'obiettivo di capire quali emozioni suscitano in noi i vari percorsi all'interno della città e provare a categorizzare le emozioni con il fine di rappresentarle. Sono state realizzate alcune mappe emozionali suddividendo le emozioni in due sole categorie, Benessere (colore rosso) e Fastidio (colore blu), e differenziando il grado di tale emozione anche grazie all'intensità del tratto. Sovrapponendo un foglio di carta lucida sulla cartografia urbana sono state ripercorse strade e vicoli indicandoli con i rispettivi tratti grafici; all'inizio le strade abituali più note e poi quelle secondarie, con il tentativo di riscoprire percorsi e ricordi di anni passati che sembravano ormai perduti.

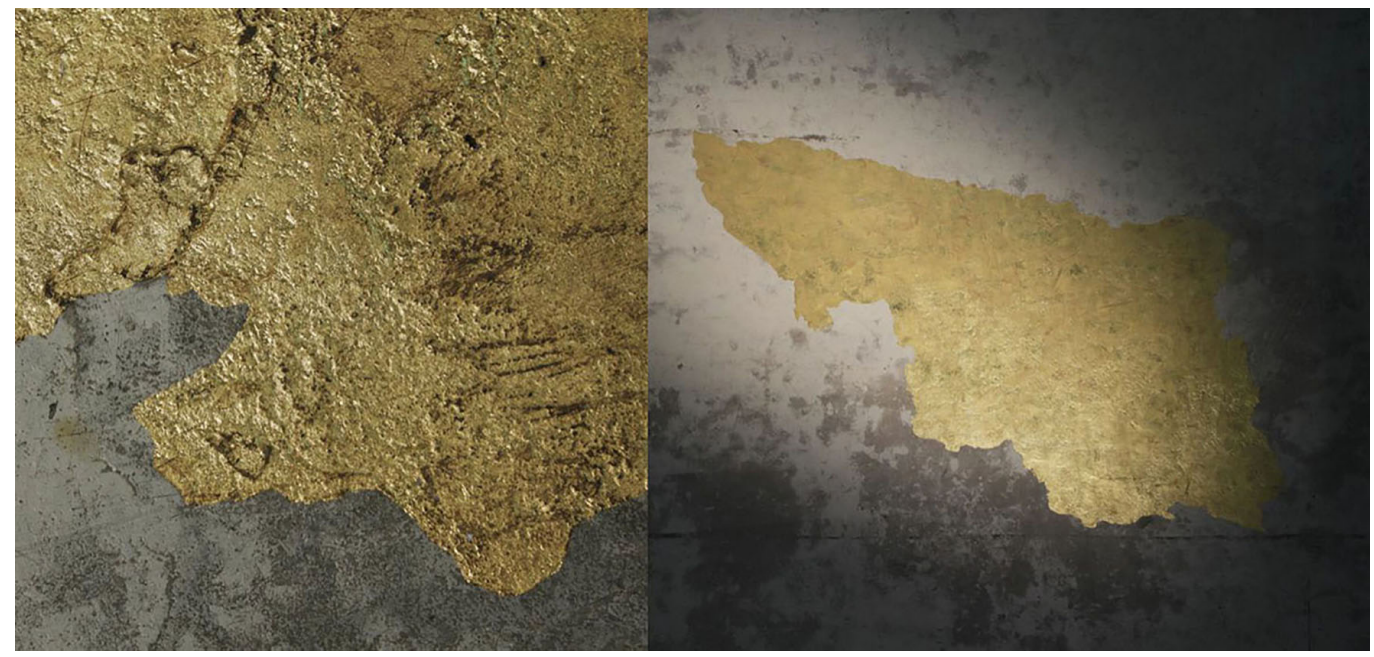


Il risultato che ne deriva, staccando il foglio sovrapposto dalla base planimetrica di Roma, è un'immagine astratta dove fili rossi, punti blu e mezze figure si vanno a volte ad incrociare. Come per le esperienze fatte dalla Saadè, si tratta di un personale ritratto urbano, che ha significato principalmente per chi lo ha disegnato. In termini visivi l'effetto è stimolante e la sovrapposizione di più livelli conduce a riscontri interessanti, ma ricercare un metodo scientifico, una suddivisione in elementi sempre catalogabili ci fa capire che il materiale potrebbe essere insufficiente perché si tratta, sempre, di immagini personali e non decodificabili in maniera univoca (fig. 8).

È importante rifarsi ai riferimenti noti e ciò che ci auspichiamo è che si possa arrivare ad un modo per visualizzare informazioni utili all'uomo per vivere e soprattutto comprendere meglio le bellezze e le criticità della città. I dati soggettivi devono essere semplificati e di facile inserimento in una scala della qualità (concetto di Benessere-Fastidio) più possibile comprensibili anche per i non addetti ai lavori. Queste informazioni, se spalmate su grandi aree, risulterebbero incomprensibili, anche di difficile gestione, ed è quindi fondamentale restringere le zone di studio. Ė obbligatorio citare il collegamento con le sperimentazioni di Kevin Lynch e il suo lavoro sulla comprensione della città, The Image of the City.

Nonostante si tratti di un testo del 1960, gli spunti che Lynch offre sono molteplici; Imageability è il termine che viene usato per indicare l'abilità di un determinato luogo o oggetto nel suscitare nell'osservatore una vivida immagine mentale dell'ambiente. L'uomo ha bisogno di punti di riferimento per decodificare lo spazio in cui si muove e Lynch, attraverso attente legende, forniva strumenti per comprendere pienamente determinati luoghi e le dinamiche relative che mettevano in atto (fig. 9).

La scelta di una direzione, in via sperimentale, ci ha dato la possibilità di prestare attenzione ai soli temi di fruibilità e percezione dello spazio sul percorso lungo Via Flaminia, uno degli assi del quartiere Flaminio che si innesta su via del Corso. Si parte da Ponte Milvio e si arriva a Piazza Venezia. È importante definire i parametri di interesse, che non devono essere numerosi e devono indicare una scala di valori e significati non troppo ampia. Ipotizzando che, in futuro, si possa arrivare a codificare un sistema comprensibile e condivisibile utilizzabile da tutti, non si realizza un tipo di legenda simile a quelle utilizzate da Lynch, cioè ricca di numerosi parametri per evitare la difficile interpretazione. II disegno si appoggia su un grafico di facile comprensione che, da sempre, è quello cartesiano con le coordinate $X$ ed $Y$

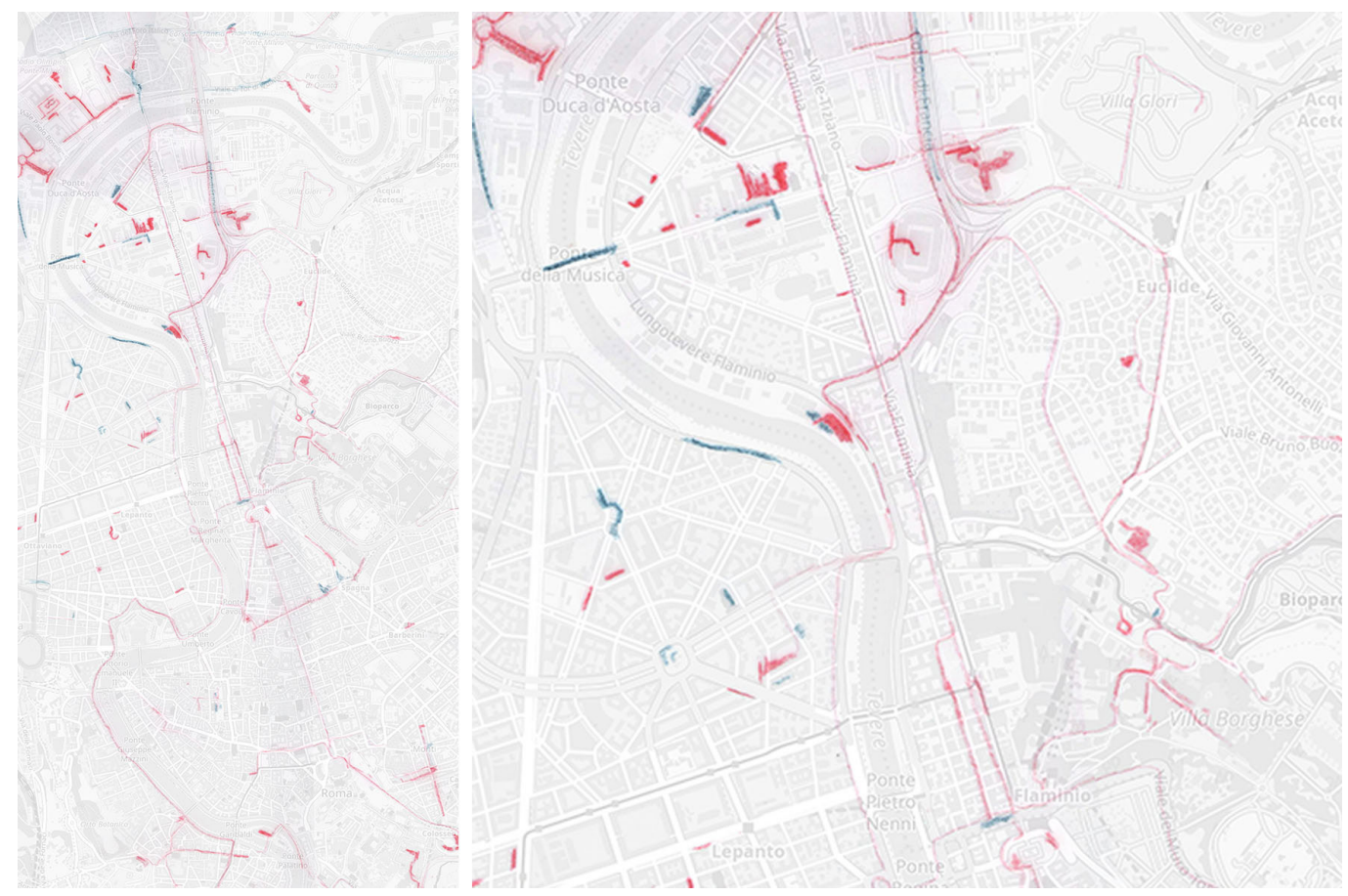


Fig. 9. Immagine da The mage of the City [Lynch 1964, p. 24].
FIG. 8. Problems of the Boston image

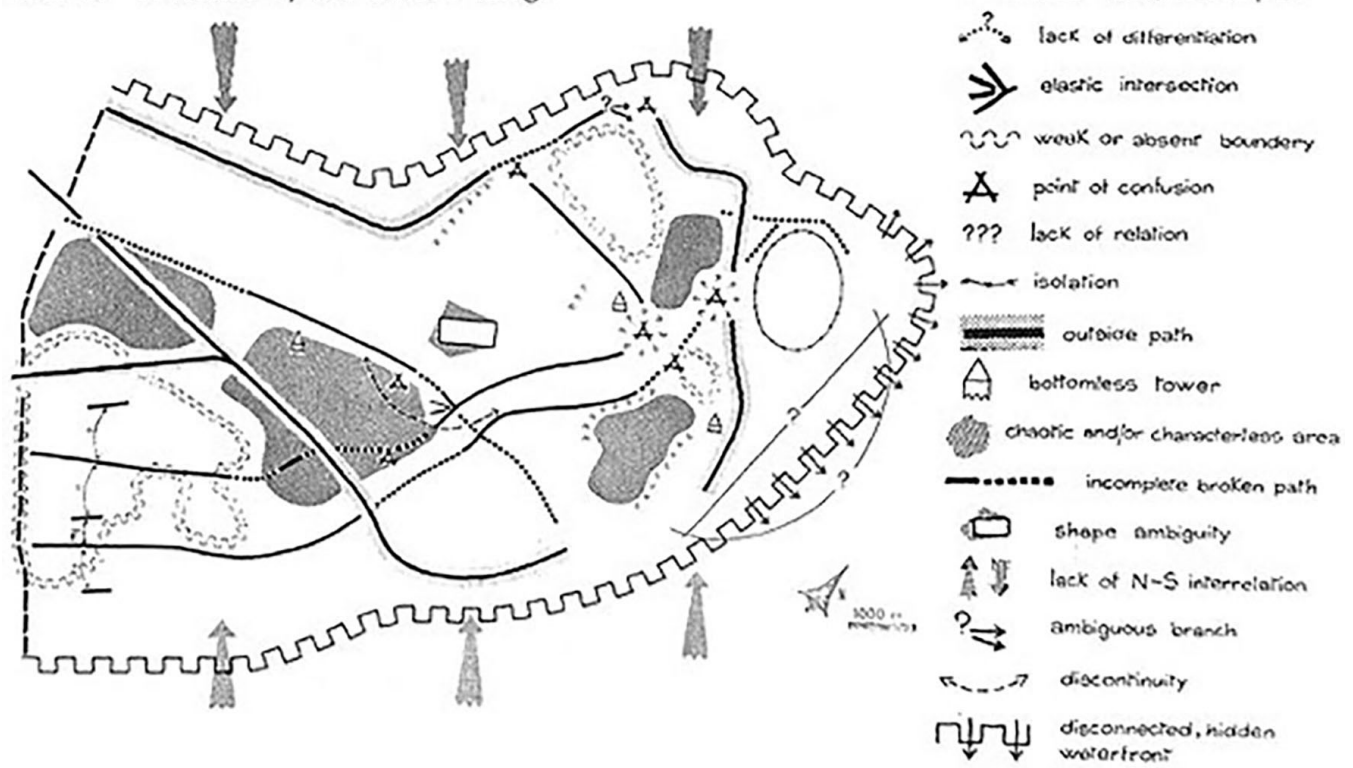

che individuano qualità e significati che esprime il luogo e che, graficamente, formano linee spezzate che proseguono lungo tutto il percorso.

Dopo alcune prove, si è deciso di disegnare solo due parametri, ognuno legato alla percezione dal punto di vista di un pedone; l'accessibilità (blu), per capire quanto è facile muoversi sulla strada e il comfort visivo (rosso) che, rifacendosi anche a Lynch, dà la possibilità di esprimere valori di soddisfazione visiva dello spazio. Vengono in parte ripresi i concetti del primo tentativo, cercando di inserirli all'interno di un meccanismo più regolato. Dopo alcune prove grafiche che presupponevano di dover scegliere un unico senso di lettura, è risultata più soddisfacente la soluzione di rappresentare i due valori, benessere e fastidio, specularmente rispetto all'asse individuato. Più le linee verticali sono basse, e quindi vicine all'asse stradale orizzontale, minore sarà il valore del relativo parametro. Visivamente il grafico esprime qualità e criticità facilmente individuabili (fig. I0).

Per sviluppare una mappa emozionale il più possibile fluida e rapida, si è scelto di sperimentare con strumentazioni di disegno digitale, al fine di esprimere i valori di accessibilità (blu) e comfort visivo (rosso) attraverso dei segni caratteristici. Questi segni digitali, realizzati tramite iPad Pro e software Procreate, sono ottenuti tramite dei pennelli digitali realizzati ad hoc: questi presentano una forma generica associata ad una spaziatura molto ampia che rende il segno grafico non continuo, ma scomposto in numerose piccole 'impronte' successive della forma del pennello, distinguibili in dettaglio ad occhio nudo ma che si confondono in un segno più continuo in una visione d'insieme. Alla pressione esercitata con la penna sul tablet viene associata una variazione di dimensione del pennello, owvero più si preme con forza e più la pennellata è ampia. Ė possibile quindi associare valori più elevati di un determinato dato che si vuole rappresentare alla pressione che si effettua con la penna nel momento in cui si copre quella porzione di mappa con il segno. Inoltre, la variazione di pressione può assumere numerosi valori diversi nel corso di un'unica pennellata, ne consegue che tramite un unico gesto è possibile esprimere molteplici valori diversi. II grafico risultante non è sicuramente preciso (non è possibile individuare valori numerici esatti), ma è il risultato di un'associazione tra la gestualità di un'esecuzione grafica e la sensazione che vi si vuole associare, ottenuta nello stesso istante nel quale si realizza, assumendo quindi un carattere di immediatezza e spontaneità che dà un valore aggiunto al grafico risultante (fig. I I).

Un altro esperimento sintetizza gli obiettivi fissati dallo studio con una diversa interpretazione grafica (fig. I2). 
Fig. 10. Federico Rebec chini, Esperimento n. 2, Mappa di Accessibilità Comfort

Fig. I I. Alekos Diacodimitri, Esperimento n. 3 , Mappa di Accessibilità Comfort.

Fig. 12. Emanuela Chiavoni, Esperimento n. 4 , Mappa di Accessibilità Comfort.
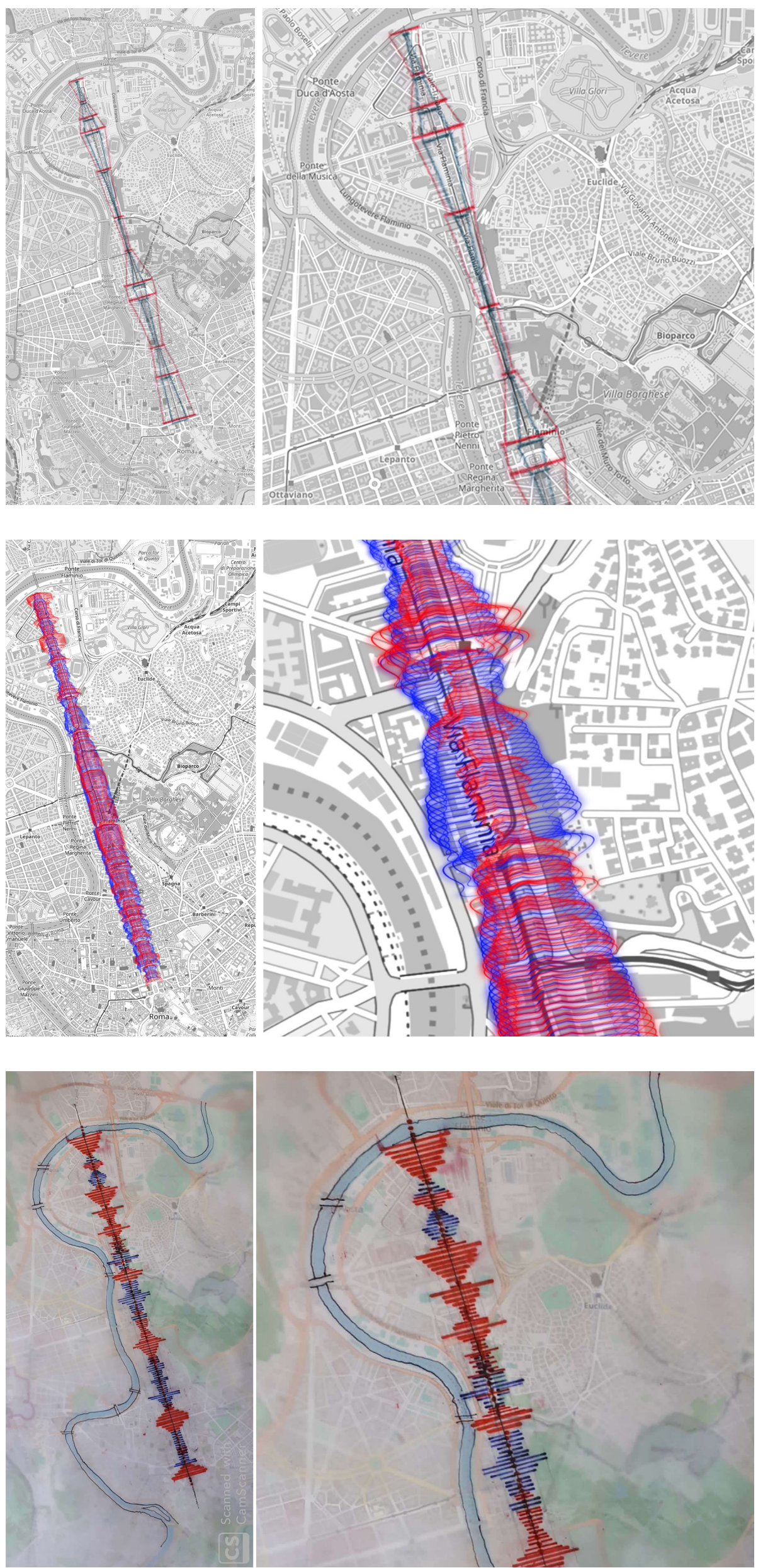


\section{Conclusioni}

La ricerca che stiamo portando avanti prevede di far svolgere a più persone queste sperimentazioni grafiche, tra la razionalità e l'emozione, e sarà proprio dalla sovrapposizione e dal confronto dei differenti risultati derivati che si potranno avere esiti interessanti. Disegnare mappe emozionali, in maniera semplificata, con la lettura delle connessioni e delle trame urbane condivise dai cittadini darà la possibilità di comprendere meglio i fenomeni urbani reali e più immateriali per favorire, nella progettazione urbana, la valorizzazione della città $[1]$.

\section{Note}

[I] II presente contributo è stato redatto in stretta collaborazione tra gli autori che hanno condiviso obiettivi, metodologie e risultati. Nello specifico si segnala che i paragrafi Introduzione e Conclusioni si devono ad Emanuela Chiavoni, i paragrafi Excursus storico e Orientamento, sensazioni, atmosfere si devono a Federico Rebecchini e il paragrafo Sperimentazioni si deve ad Alekos Diacodimitri. A Federico Rebecchini spetta la selezione critica di tutte le immagini che corredano il testo.

\section{Riferimenti bibliografici}

Baricco Alessandro (2018). The Game. Torino: Einaudi.

Friendly Michael (2005). Milestones in the History of Data Visualizations: A Case Study in Statistical Historiography. In Weihs Claus, Gaul Wolfgang (ed.). Classification - the Ubiquitous Challenge. Studies in Classification. Data Analysis, and Knowledge Organization. Berlin, Heidelberg: Springer.

Lynch Kevin (1964). The Image of the City. Cambridge, MA (USA): MIT Press.

Lupi Giorgia, Posavec Stefanie (2016). Dear Data. London: Particular Books (Penguin Books Limited).

McGuire Richard (20|4). Richard McGuire makes a book. In Five Dials, n. 35.

\section{Sitografia}

$<$ https://www.domusweb.it/it/recensioni/2017/03//7/dear_data.html >.

<https://www.kimbalbumstead.com/memorymappingdrawing>.

<www.stephaniesaade.com/pages/installations/a-map-of-good-memories.html>.

$<$ https://www.atlantedelleemozioni.it/>.

$<$ http://giorgialupi.com/>.

$<$ http://www.stefanieposavec.com/>.

\section{Autori}

Emanuela Chiavoni, Sapienza Università di Roma, emanuela.chiavoni@uniromal.it

Alekos Diacodimitri, Sapienza Università di Roma, alekos.diacodimitri@uniromal.it

Federico Rebecchini, Sapienza Università di Roma, , federico.rebecchini@uniromal.it

Per citare questo capitolo: Chiavoni Emanuela, Diacodimitri Alekos, Rebecchini Federico (2020). Sperimentazioni per visualizzare i dati della città/ Experimentation to visualize city data. In Arena A., Arena M., Brandolino R.G., Colistra D., Ginex G., Mediati D., Nucifora S., Raffa P. (a cura di). Connettere. Un disegno per annodare e tessere. Atti del $42^{\circ}$ Convegno Internazionale dei Docenti delle Discipline della Rappresentazione/Connecting. Drawing for weaving relationships. Proceedings of the 42th International Conference of Representation Disciplines Teachers. Milano: Franco Angeli, pp. 3063-3082. 


\title{
Experimentation to Visualize City Data
}

\author{
Emanuela Chiavoni \\ Alekos Diacodimitri \\ Federico Rebecchini
}

\section{Abstract}

Every day we acquire a huge amount of raw and unprocessed data. Those are informations, often intuitive perceptions, wonders, sensations that we can decide to record through a memory, a mental note or a sketch with annotations.

It can be subjective data or personal emotions, but also more objective data such as the effective functionality of an urban space.

Everything that involves intellectual recognition can help us better understand the city and our relationship with it and above all it can give us guidelines for its enhancement.

Through graphic experiments (emotional maps) within the Data Visualization, an attempt has been made to display information that is not normally associated with value scales.

Keywords

representation, visualization, graphic experimentation.

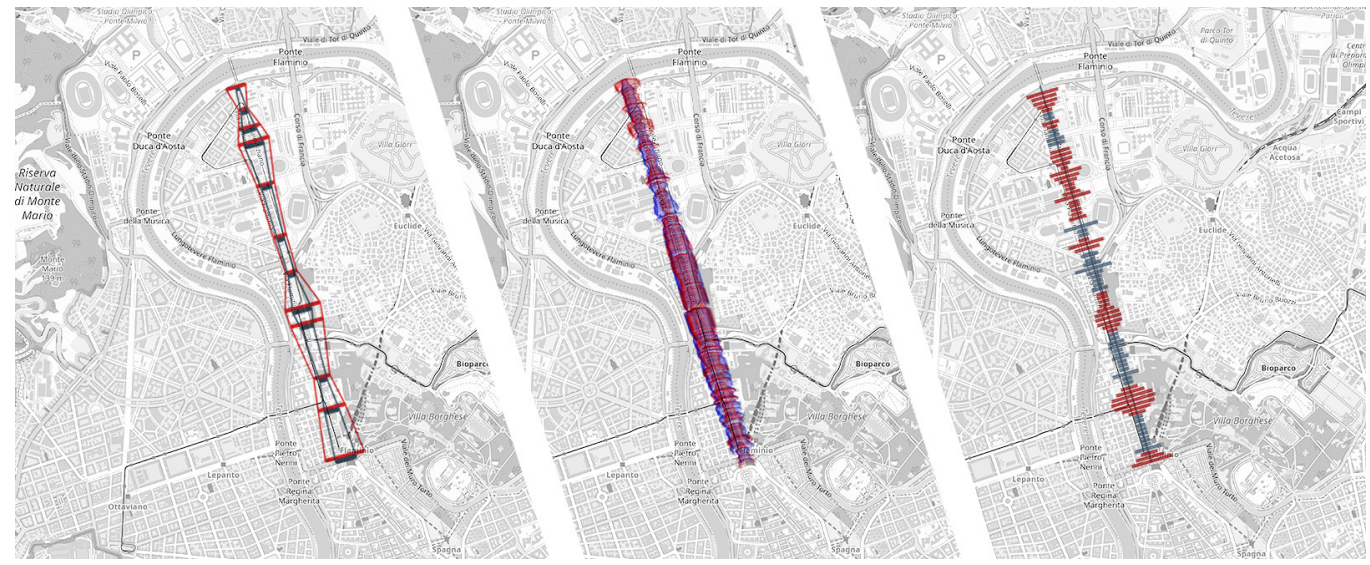




\section{Introduction}

This research starts from a project called Atlas of Emotions of the City. An initiative that has been carried out in the European Capital of Culture 2019, that is Matera. The Atlas is one of the many projects born in the context of the election of the city of Basilicata as an Italian cultural center. The collaboration between the designer Stefano Faravelli and the writer Alessandro Baricco (with the students of his Holden School) has given rise to a map with the following intentions: "[the project] proposes a new way of visiting the cities, through the use of an Emotional Map created by collecting the memories and stories of the inhabitants and, gradually, of the visitors themselves" (fig. I). The goal was to systematize, with artistic and informative purposes, memories and emotions related to the territory. The result was a series of events, dance performances, construction of machinery, drawings, illustrations, numerous texts, presented in a large exhibition space. By 'Map' is meant a mole of objects and testimonies that guide us in understanding an urban space and those who populate it. The operation of Faravelli and Baricco was an opportunity to make a body of information and emotions related to the territory physical and tangible (or at least graphic); a sensitive, artistic work that gives importance to uncountable emotional data.

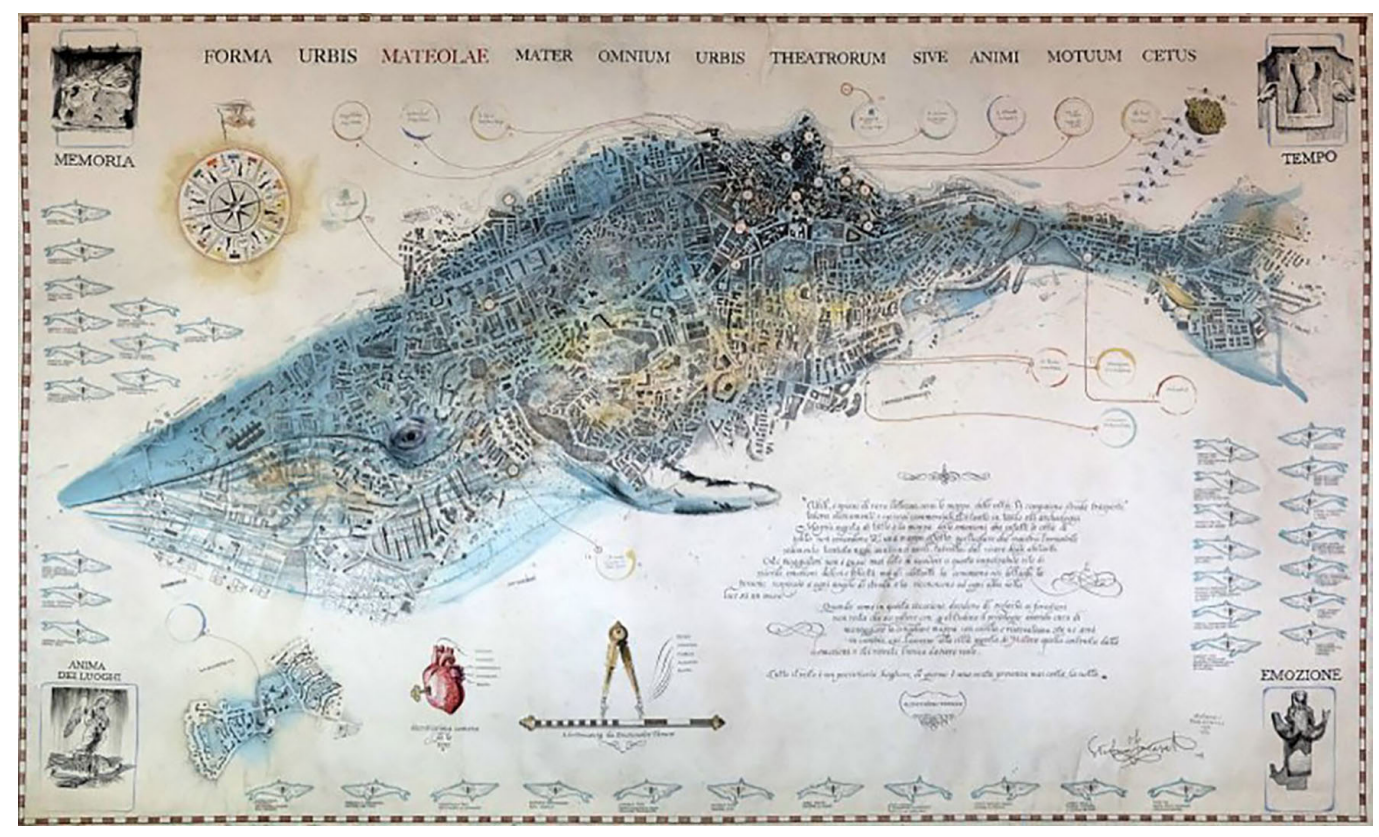

\section{Historical excursus}

The Atlas of Emotions of the City is not a unique case; the desire to systematize and graphichise data that has piled up over time with different dimensions of meaning has always been a goal for scholars and researchers. Infographics, increasingly present in periodicals and newspapers, in fact try to help us understand otherwise highly boring and difficult informations in a more intuitive and 'graphic' way.

This will to display data systematically begins in the early 1800s with William Playfair (pie charts and histograms) and evolves decades later with the contribution of Charles Minard and his famous map of the Russian expedition of Napoleon of 1812 , where he analyzed quantity, movements and temperatures of the French army all in a single elaborate. In a single image, a great deal of information was depicted with scientific care. It was a far-sighted and still visually modern representation (fig. 2). From Minard to the present day, great strides 
have been made and today we can define 'the will to visualize' a real science that has taken the name of Data Visualization. It is a liquid science, tangent to the world of design and, lately, also to that of art.

The discipline of Data Visualization seems to constantly renew itself, thanks to the tools that change and the incredible amount of raw data that we acquire every day. Raw data that in most cases is collected by large companies and stored on servers. Information of any kind awaiting processing or to be used for commercial purposes.

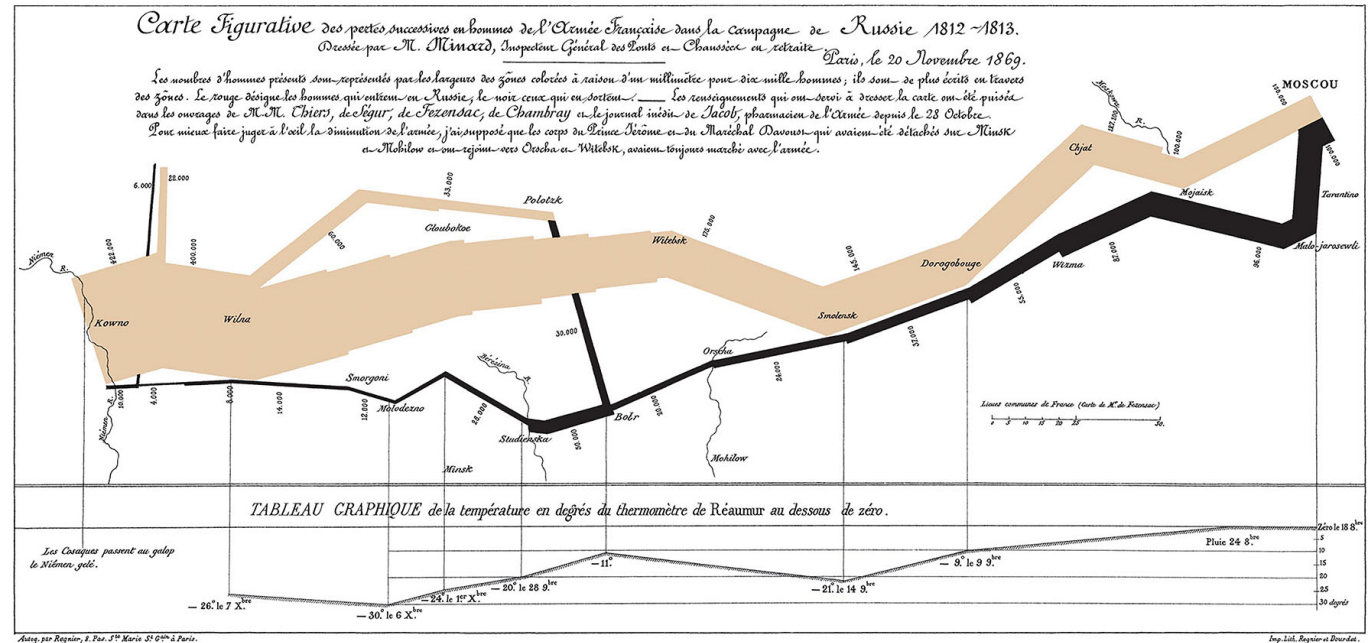

A relevant figure in this discipline is Giorgia Lupi, an Italian in New York who made data visualization her research goal; she calls herself an Information Designer because she offers a graphic form to different information. Significant is the book Dear Data, a correspondence of postcards between Lupi and Stefanie Posavec (another information designer); on each postcard sent, the two designers hand-drawn graphics of all kinds relating them to complex or insignificant information. This exercise/game led to a correspondence full of ideas
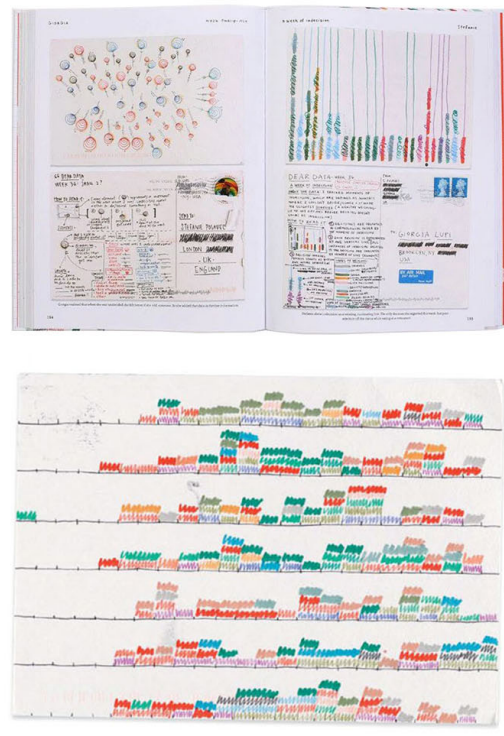

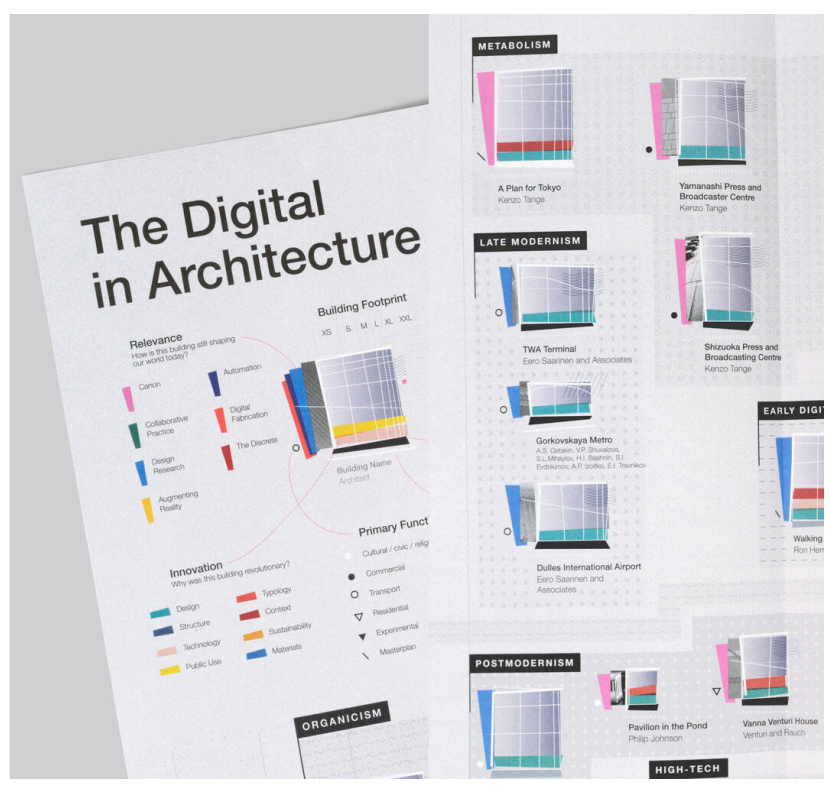

Fig. 3. Dear Data [Lupi, Posavec 2016]; Giorgia Lupi + Space 10, The Digital in Architecture, 
to make the visualization of data more complete and stimulating. Giorgia Lupi's work goes further and further in every project; from gigantic installations (The Room of Change for the Milan Triennale) to the collaboration with Space 10 for the The Digital in Architecture project where the characteristics of certain architectural currents formed elements capable of creating many small data architectures (fig. 3).

The latter project has an illustrious descendant; in 2000 the architect and theorist Charles Jencks published an image in Architectural Review inside an article called The Century is Over, Evolutionary Tree of Twentieth-Century Architecture. It is a total image that contains the various architectural currents of the century that was just finished. Jencks, author of numerous books and defender of the Post-Modern, wanted to take stock of twentieth-century architecture and decides to opt for an evolutionary tree in the form of a map. A fluid map, as are the currents. Where the movements and the different architects touch each other, widen and shrink until they disappear.The $X$ axis is the temporal one, the $Y$ axis instead represents the approach of each movement to architecture. The result is a coherent map, not objective of course, but which briefly give us a picture of a century of architecture (fig. 4).

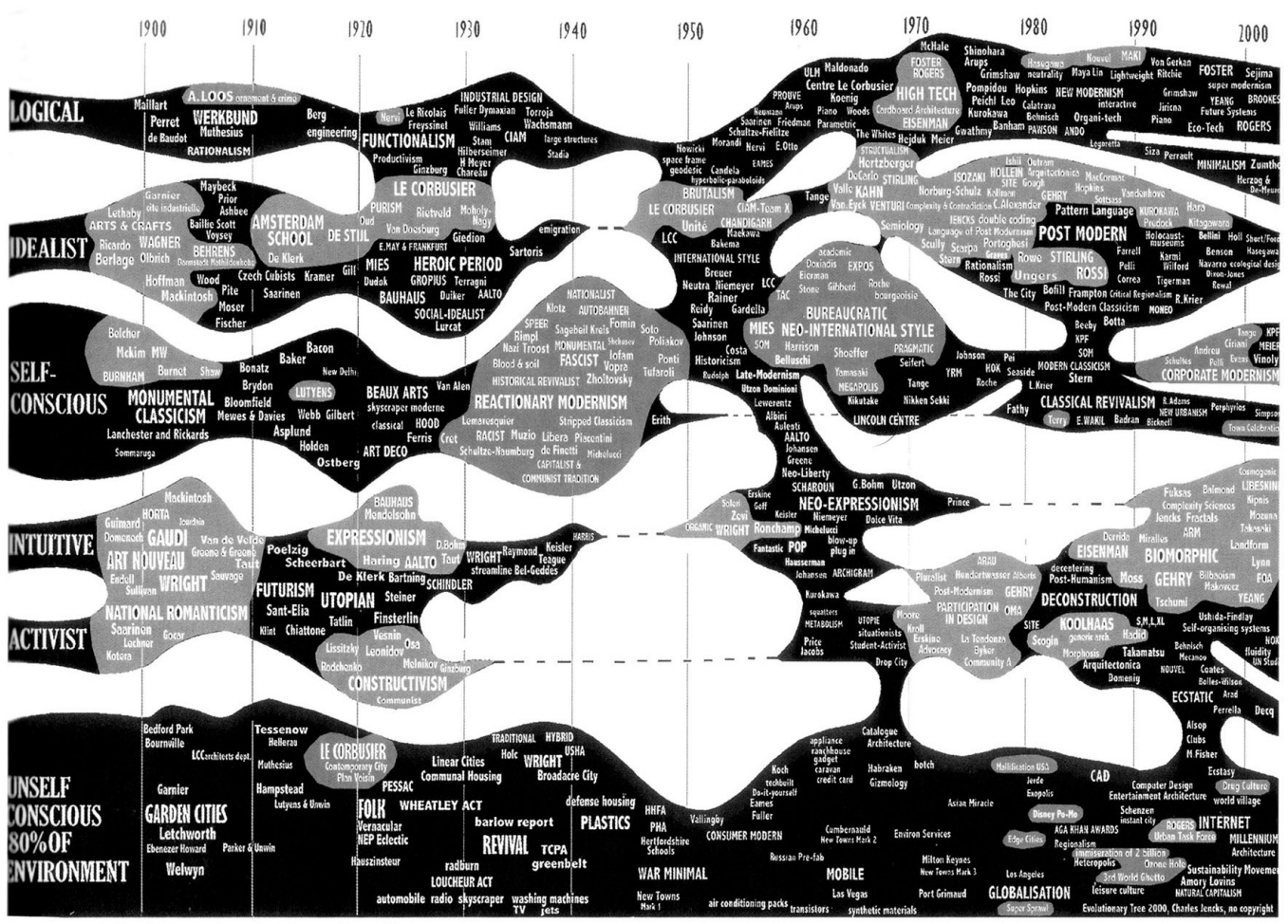

If in Jencks we find clarity of purpose, we cannot say otherwise of a map that tries to visualize the digital revolution. Baricco's analysis in his book The Game makes us go through the transformations that new technologies have brought to our way of living and thinking. Each chapter outlines part of a Mappa Mundi that serves to orientate the reader within this journey. He imagines some small islands, each one is a significant step in the ongoing revolution and then the individual events, such as the birth of Facebook, are mountains. The reader follows a flow, a river, which drags from one revolution to another, always in motion. The concept is very interesting even if the maps do not add anything to the narration. They are images for their own sake, without correlation with the contents they express if not 
the names of the companies placed above. The complete map allows us to see the journey made, but not to display fundamental information such as dates, relevant characters and ideology, visible instead in the Jencks map. Probably even something similar may be useful to find your way in uncharted territories (fig. 5).

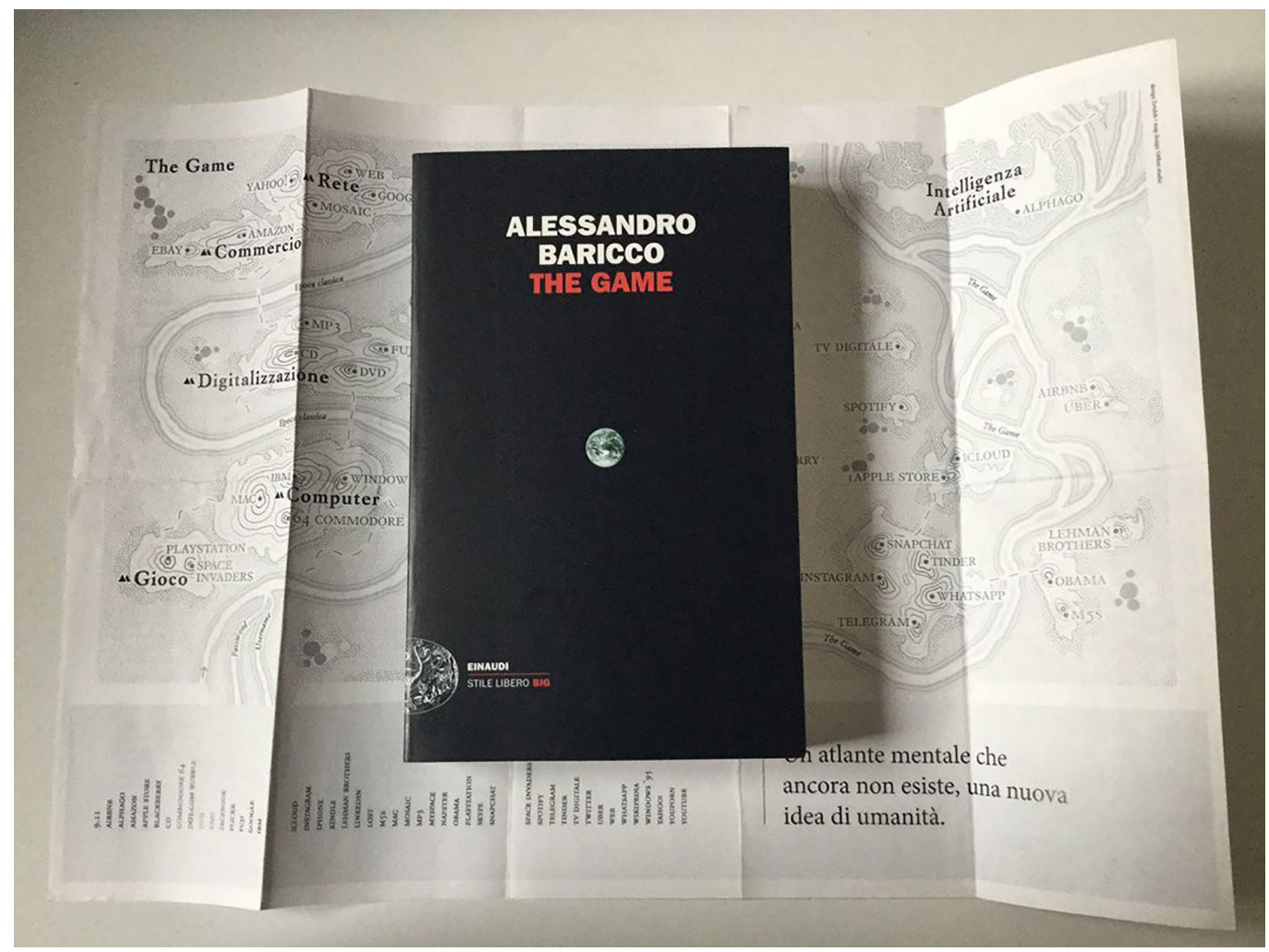

\section{Orientation, sensations, atmospheres}

When we enter the field of emotions and memories, the situation becomes more complicated; representing such ephemeral, uncountable and difficult to describe elements is a particularly difficult task.

In most cases it is mandatory to rely on an abstraction of these emotions in a purely subjective form. Everyone channels them towards a medium in a very personal way and it is therefore difficult to superimpose the results.

An example of how such random data can be represented is that of Remì, the mouse protagonist of the Pixar film Ratatouille. Remì merges flavors and emotions into his head and generates a succession of shapes that twist and sometimes explode (fig. 6). Intangible data is displayed always with new colors and figures, linked by personal taste parameters. If in the Pixar film the intent is to add something to a narration through images, the situation is different for the Lebanese artist Stephanie Saadè, who in 2015 created an artwork called A Map of Good Memories. Taking a map of Lebanon, she traced the trajectories of the travels she usually did to go meet the people she loves or to visit particular places. All the combined trajectories have given shape to a tangle within a closed form. The latter, completely captured in gold, becomes a sentimental territory, a geographical portrait of the artist, drawn on the floor. Saadè manages to graphically represent a multitude of very personal information (fig. 7). 

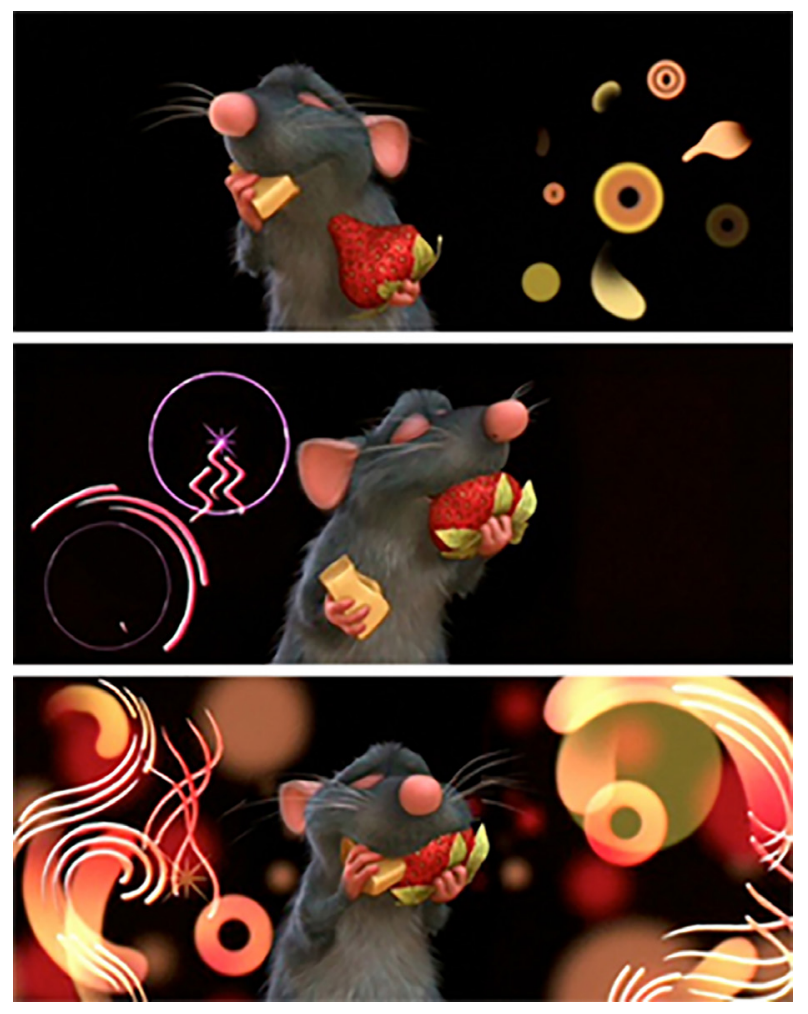

\section{Experimentations}

The first research hypothesis was to work on a personal emotional map of the city, delimiting the range of action and analysis to an area of the city of Rome. A job necessarily inspired by the work of Saadè, a job with the aim of understanding what emotions the various paths within the city arouse in us. But also trying to categorize emotions with the aim of representing them. Some emotional maps were created by dividing the emotions into only two categories, Comfort (red color) and Discomfort (blue color), and differentiating the degree of this emotion also thanks to the intensity of the stroke. By superimposing a sheet of tracing paper on the urban cartography, roads and alleys have been re-traced. At the beginning the well-known usual streets and then the secondary ones, with the attempt to rediscover paths and memories of past years that seemed now lost.

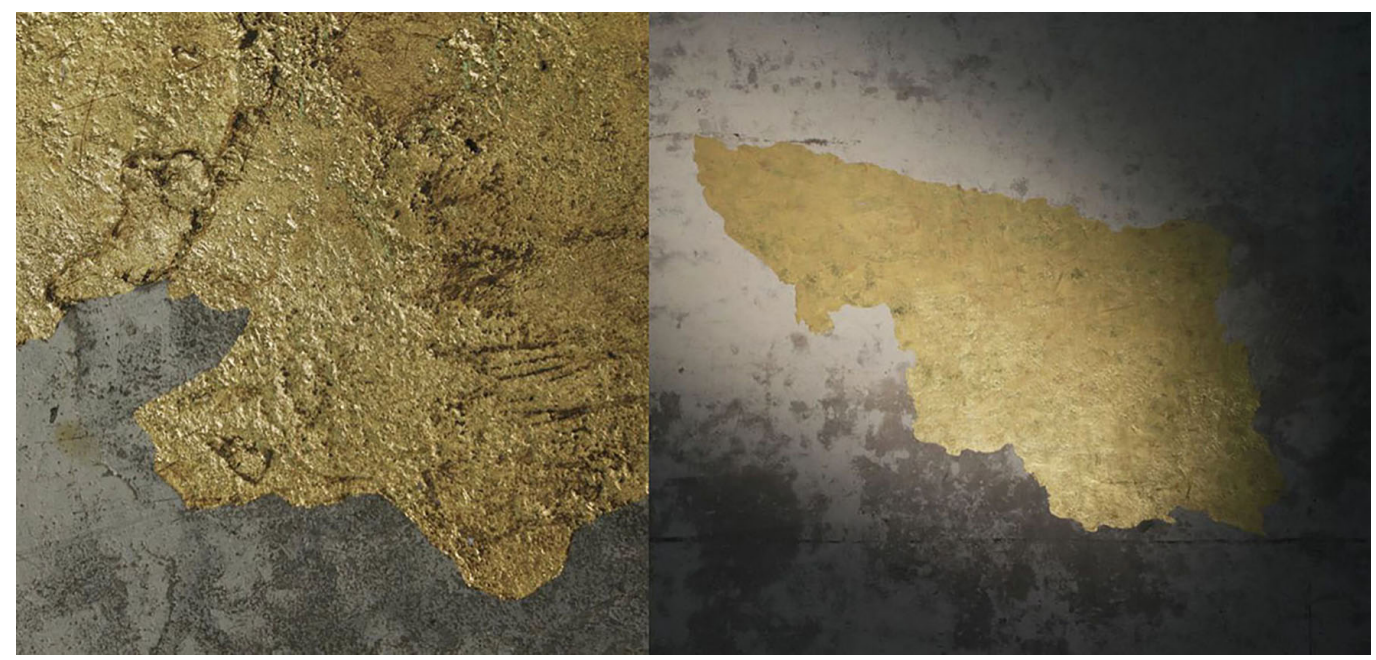


The result from detaching the overlapping sheet from the planimetric base of Rome is an abstract image where red threads, blue points and half figures sometimes cross each other. As with the experiences made by Saadè, it is a personal urban portrait, which has meaning mainly for those who designed it. In visual terms the effect is stimulating and the overlapping of several levels leads to interesting findings. But if we are looking for a scientific method, or a subdivision into always catalogable elements, we understand that the material may be insufficient because we are dealing with personal images, something that is not unambiguously decodable (fig. 8).

It is important to lean on known references and what we hope is that we can come up with a way to display information useful to live into the city, but also to better understand the beauty and critical issues of the urban tissue. The subjective data must be simplified and easy to insert in a quality scale (concept of comfort and discomfort) as comprehensible as possible even for non-professionals. This information, if spread over large areas, would be incomprehensible, even difficult to manage, and it is therefore essential to restrict the study area. It is mandatory to mention the link with Kevin Lynch's experiments and his work on understanding the city, The Image of the City.

Although it is a 1960 text, the ideas that Lynch offers are manifold; Imageability is the term that is used to indicate the ability of a particular place or object to arouse a vivid mental image of the environment in the observer. Human beings need reference points to decode the space in which they move and Lynch, through careful legends, provided tools to fully understand certain places and the relative dynamics they put in place (fig. 9).

The choice of a direction, experimentally, has given us the opportunity to pay attention only to the themes of usability and perception of space on the path along Via Flaminia, one of the axes of the Flaminio district that is grafted onto Via del Corso. It starts from Ponte Milvio and arrives to Piazza Venezia. It is important to define the parameters of interest, which must not be numerous. Assuming that, in the future, it will be possible to codify a comprehensible and shareable system that can be used by all, we chose to avoid a type of legend similar to those used by Lynch, that is rich in numerous parameters. The drawing lean on an easy-to-understand chart, in this case the Cartesian one with the $X$ and $Y$ coordinates that identify the qualities and meanings that the place expresses. These values graphically form broken lines that continue along the entire path.

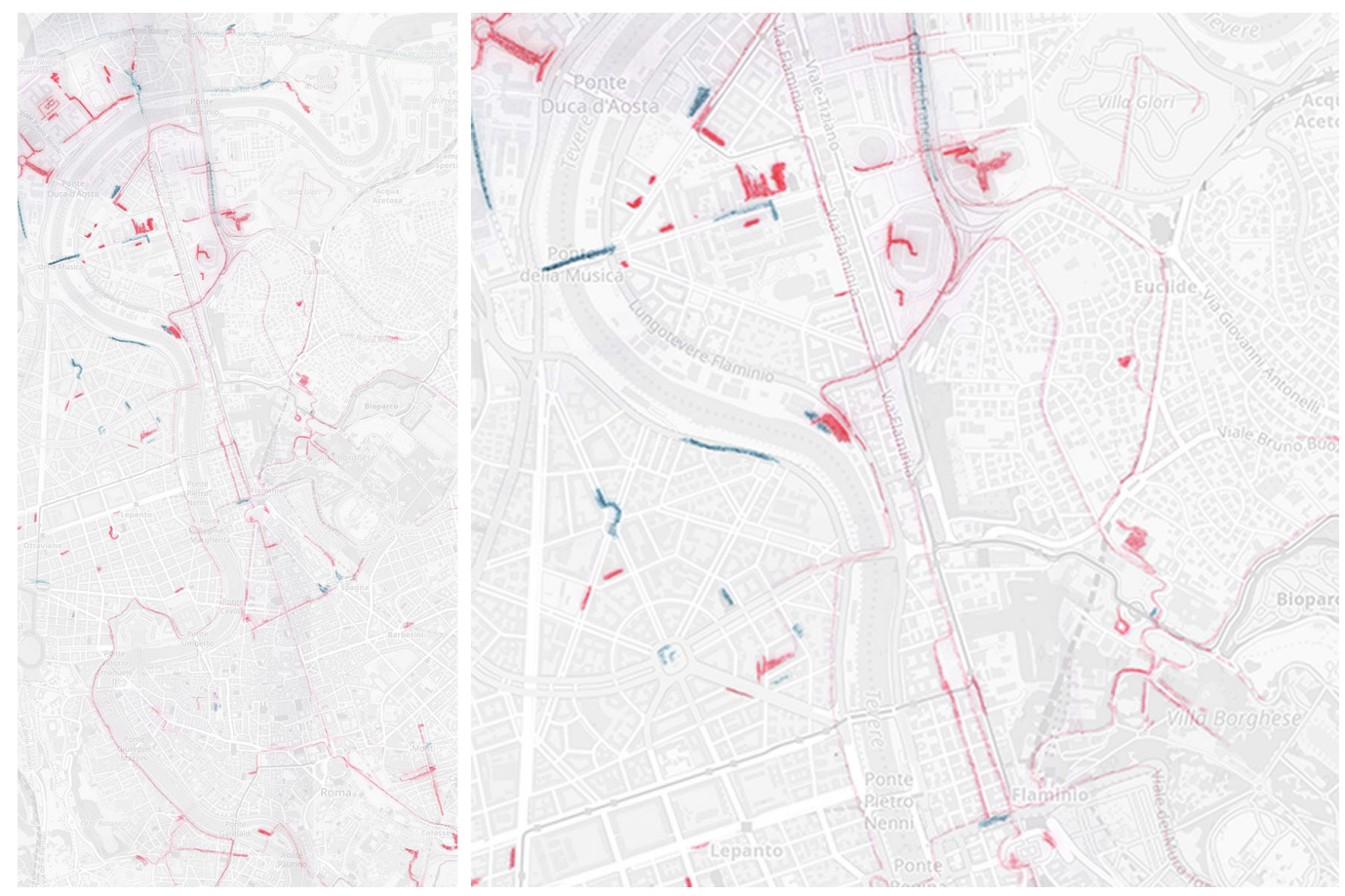


FIG. 8. Problems of the Boston image

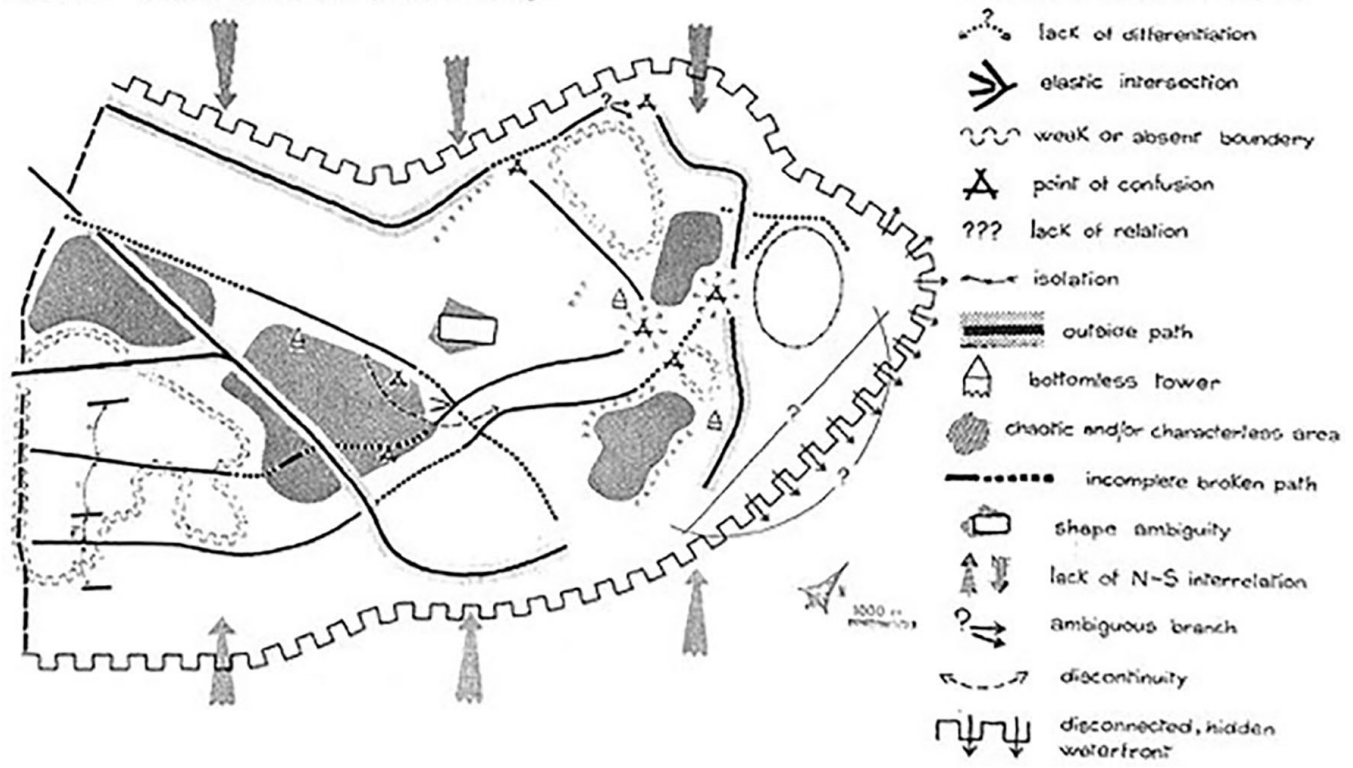

After some tests, it was decided to draw only two parameters, each linked to the perception from the point of view of a pedestrian; Accessibility (blue), to understand how easy it is to move on the road, and Visual comfort (red) which, referring also to Lynch, gives the opportunity to express the visual satisfaction of the space. The concepts of the first attempt are partially taken up, trying to insert them within a more regulated mechanism. After some graphic tests which presupposed having to choose a single sense of reading, the solution of representing the two values mirroring the axis identified, was more satisfactory. The lower the vertical lines, the lower the value of the relative parameter.Visually the graph expresses easily identifiable quality and criticality (fig. 10 ).

To develop an emotional map that is as fluid and rapid as possible, we have chosen to experiment with digital drawing instruments, in order to express the values of accessibility (blue) and visual comfort (red) through characteristic signs. These digital signs, made using iPad Pro and Procreate software, are obtained through ad hoc digital brushes: these have a generic shape associated with a very large spacing that makes the graphic sign not continuous, but broken down into numerous successive small 'footprints'. The shape of the brush is distinguishable in detail with the naked eye, but it merges into a more continuous sign in an overview. The pressure exerted with the pen on the tablet is associated with a variation in the size of the brush, i.e. the harder you press and the wider the brush stroke. It is therefore possible to associate higher values of a given datum that you want to represent with the pressure that you make with the pen when you cover that portion of the map with the sign. Furthermore, the pressure variation can take on numerous different values over the course of a single brush stroke, it follows that with a single gesture it is possible to express multiple different values. The resulting graph is certainly not precise (it is not possible to identify exact numerical values), but it is the result of an association between the gestures of a graphic execution and the feeling that you want to associate with it, obtained at the same moment in which it is made, thus assuming a character of immediacy and spontaneity which gives added value to the resulting graph (fig. I I).

Another experiment summarizes the objectives set by the study with a different graphic interpretation (fig. 12). 
Fig. 10. Federico Rebec chini, Experiment n. 2, Accessibility and Comfort

Fig. I I. Alekos Diacodimitri, Experiment n. 3 Accessibility and Comfort Map.

Fig. 12. Emanuela Chiavoni, Experiment n. 4, Accessibility and Comfort Map.
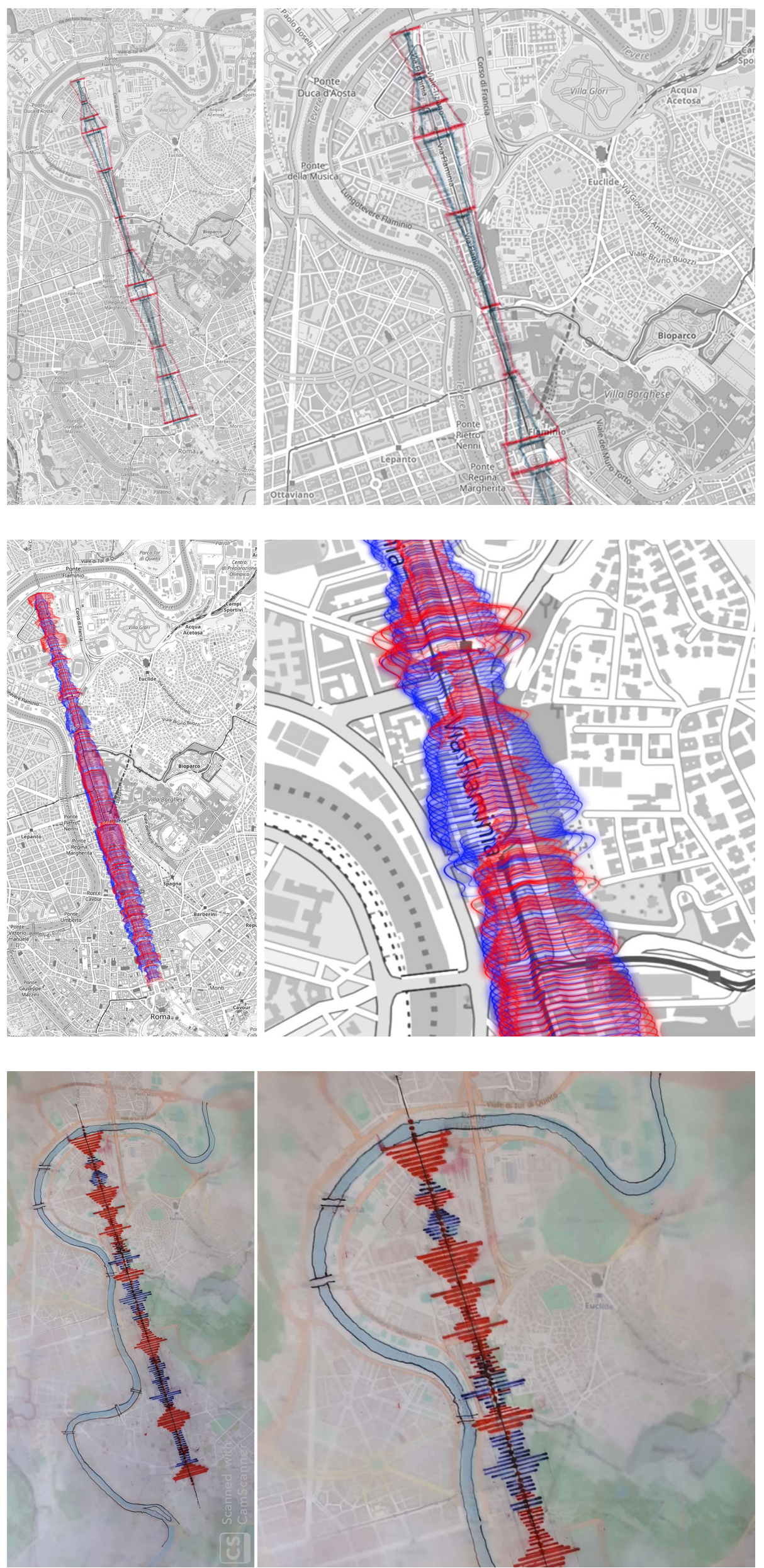


\section{Conclusions}

The research we are carrying out involves the possibility of making more people engage with these graphic experiments, between rationality and emotion. It will be the overlapping and comparison of the different works that will give us interesting results. Drawing emotional maps, even in a simple way, will give us the opportunity to better understand the urban phenomena, the connections, the plots shared by citizens, allowing a better planning and therefore an enhancement of the city $[\mathrm{I}]$.

\section{Notes}

[I] This contribution has been written in close collaboration between the authors who shared objectives, methodologies and results. Specifically, it should be noted that the paragraphs Introduction and Conclusions are due to Emanuela Chiavoni, the paragraphs Historical Excursus and Orientation, sensations, atmospheres are due to Federico Rebecchini and the paragraph Experiments is due to Alekos Diacodimitri. Federico Rebecchini is responsible for the critical selection of all the images that accompany the text.

\section{References}

Lynch Kevin (1964). The Image of the City. Cambridge, MA (USA): MIT Press.

Friendly Michael (2005). Milestones in the History of Data Visualizations: A Case Study in Statistical Historiography. In Weihs Claus, Gaul Wolfgang (ed.). Classification - the Ubiquitous Challenge. Studies in Classification. Data Analysis, and Knowledge Organization. Berlin, Heidelberg: Springer.

McGuire Richard (20|4). Richard McGuire makes a book. In Five Dials, n. 35.

Lupi Giorgia, Posavec Stefanie (2016). Dear Data. London: Particular Books (Penguin Books Limited)

Baricco Alessandro (2018). The Game. Torino: Einaudi.

\section{Website}

<https://www.domusweb.it/it/recensioni/2017/03/I7/dear_data.html >

<https://www.kimbalbumstead.com/memorymappingdrawing >

<www.stephaniesaade.com/pages/installations/a-map-of-good-memories.html>.

$<$ https://www.atlantedelleemozioni.it/>

$<$ http://giorgialupi.com/>.

$<$ http://www.stefanieposavec.com/>.

\section{Authors}

Emanuela Chiavoni, Sapienza Università di Roma, emanuela.chiavoni@uniromal.it

Alekos Diacodimitri, Sapienza Università di Roma, alekos.diacodimitri@uniromal.it

Federico Rebecchini, Sapienza Università di Roma, , federico.rebecchini@uniromal.it

To cite this chapter. Chiavoni Emanuela, Diacodimitri Alekos, Rebecchini Federico (2020). Sperimentazioni per visualizzare i dati della città/Experimentation to visualize city data. In Arena A., Arena M., Brandolino R.G., Colistra D., Ginex G., Mediati D., Nucifora S., Raffa P. (a cura di). Connettere. Un disegno per annodare e tessere. Atti del $42^{\circ}$ Convegno Internazionale dei Docenti delle Discipline della Rappresentazione/Connecting. Drawing for weaving relationships. Proceedings of the 42th International Conference of Representation Disciplines Teachers. Milano: FrancoAngeli, pp. 3063-3082. 